\title{
DATA QUALITY OBJECTIVES FOR SELECTING WASTE SAMPLES FOR BENCH-SCALE REFORMER TREATABILITY STUDIES
}

D.L. Banning

Washington River Protection Solutions

Richland, WA 99352

U.S. Department of Energy Contract DE-AC27-08RV14800

$\begin{array}{lll}\text { EDT/ECN: } & \text { DRF } & \text { UC: N/A } \\ \text { Cost Center: } & \text { 2GB00 } & \text { Charge Code: } \\ \text { B\&R Code: } & \text { N/A } & \text { Total Pages: } 18\end{array}$

Key Words: Data Quality Objective, DQO, Bench-Scale Reformer, FBSR, Analysis, Archived Samples.

Abstract: This document describes the data quality objectives to select archived samples located at the 222-S Laboratory for Bench-Scale Reforming testing. The type, quantity, and quality of the data required to select the samples for Fluid Bed Steam Reformer testing are discussed.

TRADEMARK DISCLAIMER. Reference herein to any specific commercial product, process, or service by trade name, trademark, manufacturer, or otherwise, does not necessarily constitute or imply its endorsement, recommendation, or favoring by the United States Government or any agency thereof or its contractors or subcontractors.
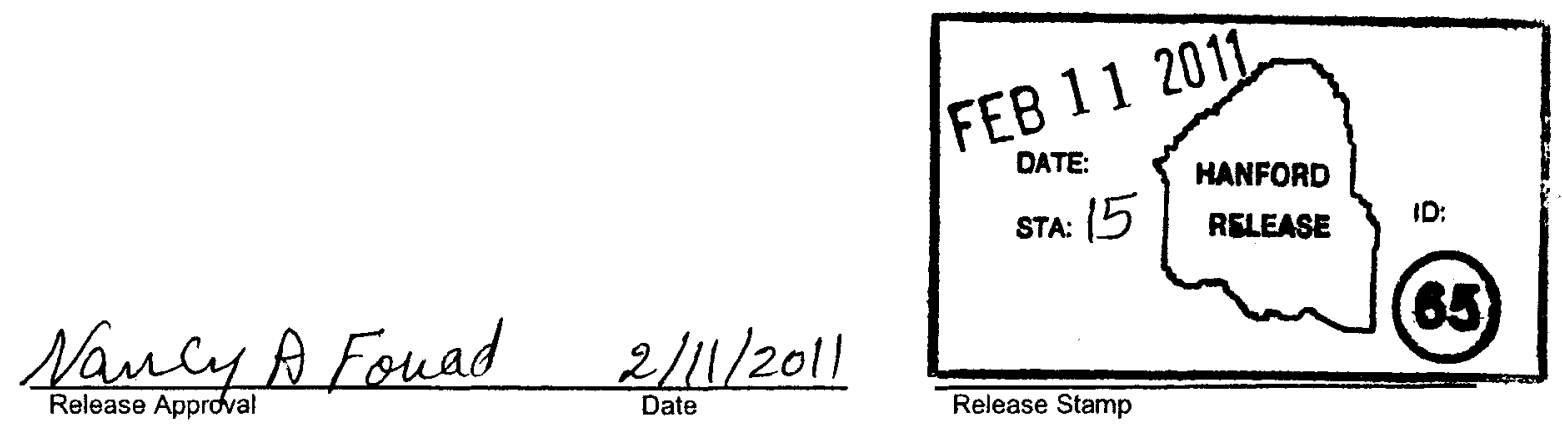

Approved For Public Release 


\begin{tabular}{|c|c|c|c|}
\hline \multicolumn{2}{|r|}{$\begin{array}{l}\text { Tank Operations Contractor (TOC) } \\
\text { RECORD OF REVISION }\end{array}$} & $\begin{array}{l}\text { (1) Document Number: } \\
\text { RPP-47073 }\end{array}$ & Page 1 \\
\hline \multicolumn{4}{|c|}{$\begin{array}{l}\text { (2) Title: } \\
\text { Data Quality Objectives for Selecting Waste Samples for Bench-Scale Reformer Treatability Studies }\end{array}$} \\
\hline \multicolumn{4}{|c|}{ Change Control Record } \\
\hline \multirow{2}{*}{$\begin{array}{c}(3) \\
\text { Revlsion }\end{array}$} & \multirow{2}{*}{ (4) Description of Change - Replace, Add, and Delete Pages } & \multicolumn{2}{|c|}{ Authorized for Release } \\
\hline & & (5) Resp. Engr. (print/sign/date) & (6) Resp. Mgr. (print/sign/date) \\
\hline 0 & Released with DRF on 8-3-10 & D. L. Banning & J. G. Reynolds \\
\hline 1 & Complete revision. Released with DRF. & D. L. Banning & J. G. Reynolds \\
\hline${ }^{2}$ RO & Complete revision. Released with DRF & $\begin{array}{l}\text { D. L. Banning 02/08/2011 } \\
\text { Dz Bamming }\end{array}$ & J. G. Reypolds poto8/2011 \\
\hline & & & \\
\hline & & & \\
\hline & & & \\
\hline & & & \\
\hline & & & \\
\hline & & & \\
\hline & & & \\
\hline & & & \\
\hline & & & \\
\hline & & & \\
\hline & & & \\
\hline & & & \\
\hline & & & \\
\hline & & & \\
\hline & & & \\
\hline & & & \\
\hline & & & \\
\hline
\end{tabular}


$\mathrm{KPP} \sim 47073$

Revision 2

\title{
DATA QUALITY OBJECTIVES FOR SELECTING WASTE SAMPLES FOR BENCH-SCALE REFORMER TREATABIITT Y STUDIES
}

\author{
D. I. Banning \\ Weskitagton Kiver Wrotection Solutions
}

Date Published

Fiebruary 2011

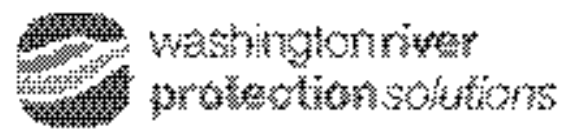

Pust (Jfrieg Bor 850

Richland. Washington

Prepared for the T.S. Department of Junderg

Olfice of Ritur Ptotectioth

Anproved for public rele ase: distribution unlimited 


\section{TABLE OF CONTENTS}

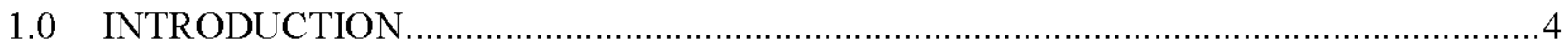

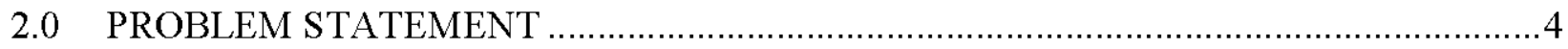

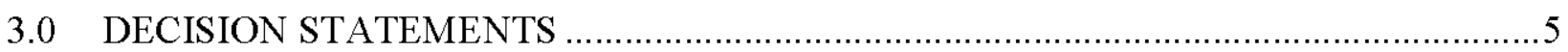

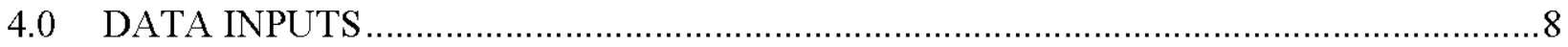

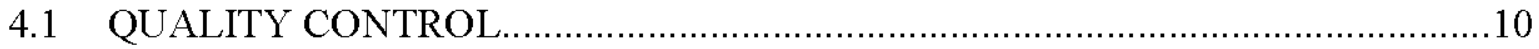

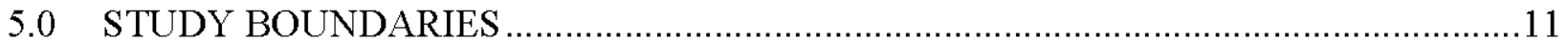

5.1 SPATIAL AND TEMPORAL BOUNDARIES ...............................................12

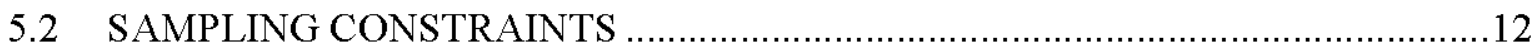

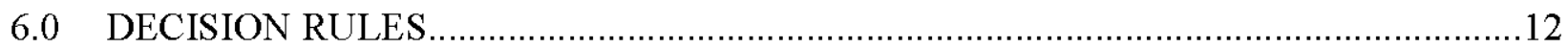

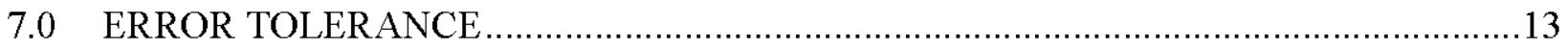

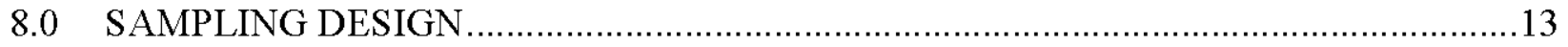

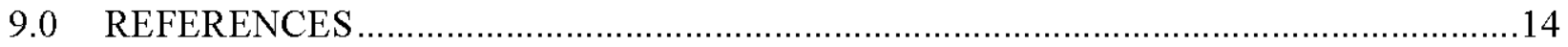

\section{LIST OF FIGURES}

Figure 3-1. Logic Flow Chart for Selection of the First Two Samples ................................... 6

Figure 3-2. Logic Flow Chart for Selection of the Third Sample ............................................ 7

\section{LIST OF TABLES}

Table 4-1. Required Information and Action Limits ...................................................... 9

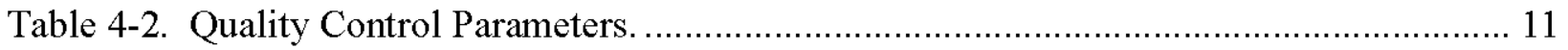


RPP-47073 Rev. 2

\section{LIST OF TERMS}

Abbreviations and Acronyms
$\begin{array}{ll}\text { BSR } & \text { bench scale reformer } \\ \text { DOECAP } & \text { Department of Energy Consolidated Audit Program } \\ \text { DQO } & \text { data quality objective } \\ \text { PSQ } & \text { principle study questions } \\ \text { QA } & \text { quality assurance } \\ \text { QSAS } & \text { Quality Systems for Analytical Services }\end{array}$




\subsection{INTRODUCTION}

In order to maximize the efficiency and minimize the time to treat Hanford tank waste in the Waste Treatment and Immobilization Plant, additional treatment processes may be required. One of the potential treatment processes is the fluidized bed steam reformer. A determination of the adequacy of the fluidized bed steam reformer process to treat Hanford tank waste is required. The initial step in determining the adequacy of the fluidized bed steam reformer process is to select archived waste samples from the 222-S Laboratory that will be used in a bench scale tests. Analyses of the selected samples will be required to confirm the samples meet the shipping requirements and for comparison to the bench scale reformer (BSR) test sample selection requirements.

This document describes the Data Quality Objective (DQO) process undertaken to ensure appropriate samples are selected to support BSR testing. The DQO process was implemented in accordance with TFC-ENG-CHEM-C-16, Data Quality Objectives for Sampling and Analyses and the U.S. Environmental Protection Agency EPA QA/G4, Guidance on Systematic Planning Using the Data Quality Objectives Process. As stated in these documents, the DQO process is iterative. Therefore, changes to this DQO document will be made during the project if data are obtained that change the requirements or if additional requirements or data are needed. As the BSR testing proceeds and data to support the testing are obtained, specific constituents for analysis can be added or deleted from the document as required.

In addition to this DQO document, other documents will be prepared to guide the overall testing program including test plans for the sample preparation and analysis, sample selection using existing data, BSR testing, and the subsequent analysis of samples.

\subsection{PROBLEM STATEMENT}

The objective of a problem statement is to clearly define the problem (the reason analytical data are required) so the focus of the project (selecting archived waste samples for the BSR testing) will be unambiguous.

With the objective of the problem statement and the focus of this DQO process in mind the problem statement can be written as follows:

Select appropriate archived samples from the 222-S Laboratory that meet the requirements for shipping and BSR testing sample selection.

The primary study question developed from the problem statement can be stated as:

Can the archived samples selected from the 222-S Laboratory meet the radionuclide requirements for shipping and BSR testing sample selection? 


\subsection{DECISION STATEMENTS}

Decision statements are developed by combining principle study questions (PSQ) with alternative actions. The PSQ identifies key unknown conditions or unresolved issues that reveal the solution to the problem. Alternative actions are the possible actions that might be taken once a PSQ has been resolved.

The decision statement is as follows:

Determine whether the selected archived samples from the 222-S Laboratory meet the radionuclide requirements for shipping and BSR testing and can be shipped or requires additional radionuclide removal, selection of additional or other archived samples, or discontinuation of sample selection.

Figures 3-1 and 3-2 show the general logic flow chart for selecting Hanford waste samples for the BSR testing. The flow charts show the decisions and activities covered by this DQO document needed to address sample selection for BSR testing. 
Figure 3-1. Logic Flow Chart for Selection of the First Two Samples

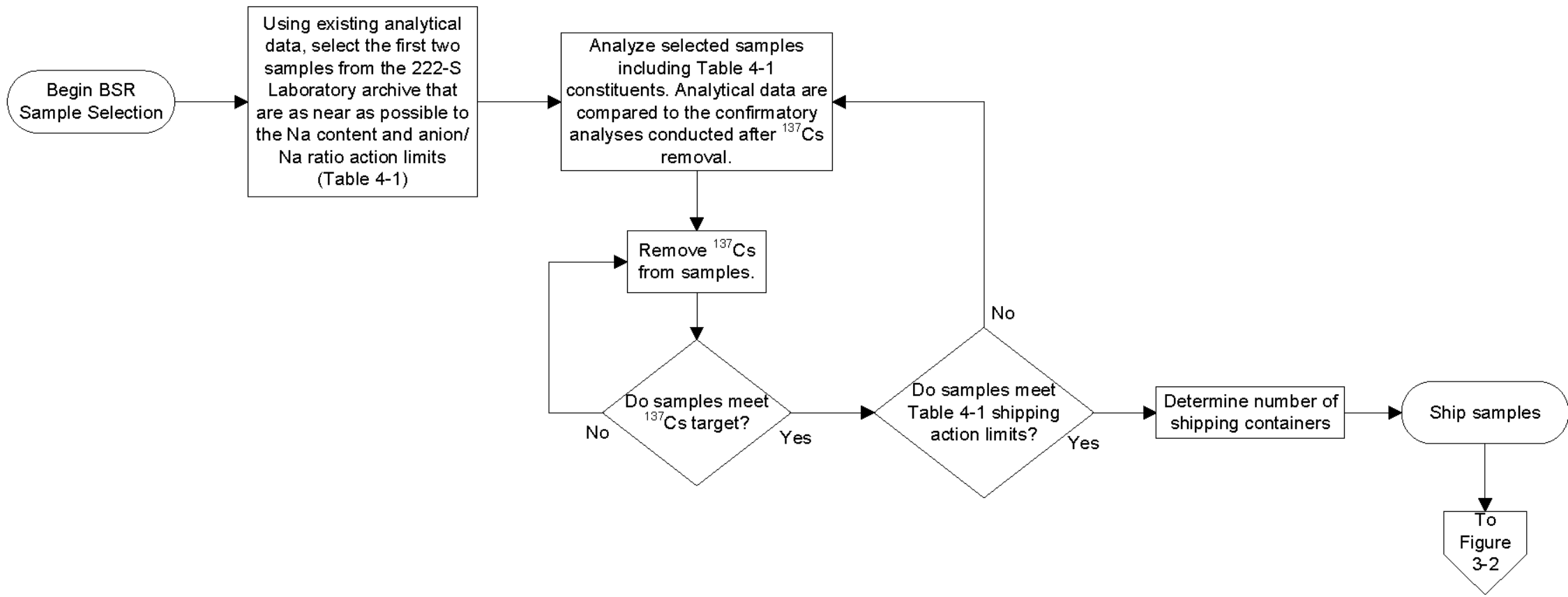


Figure 3-2. Logic Flow Chart for Selection of the Third Sample

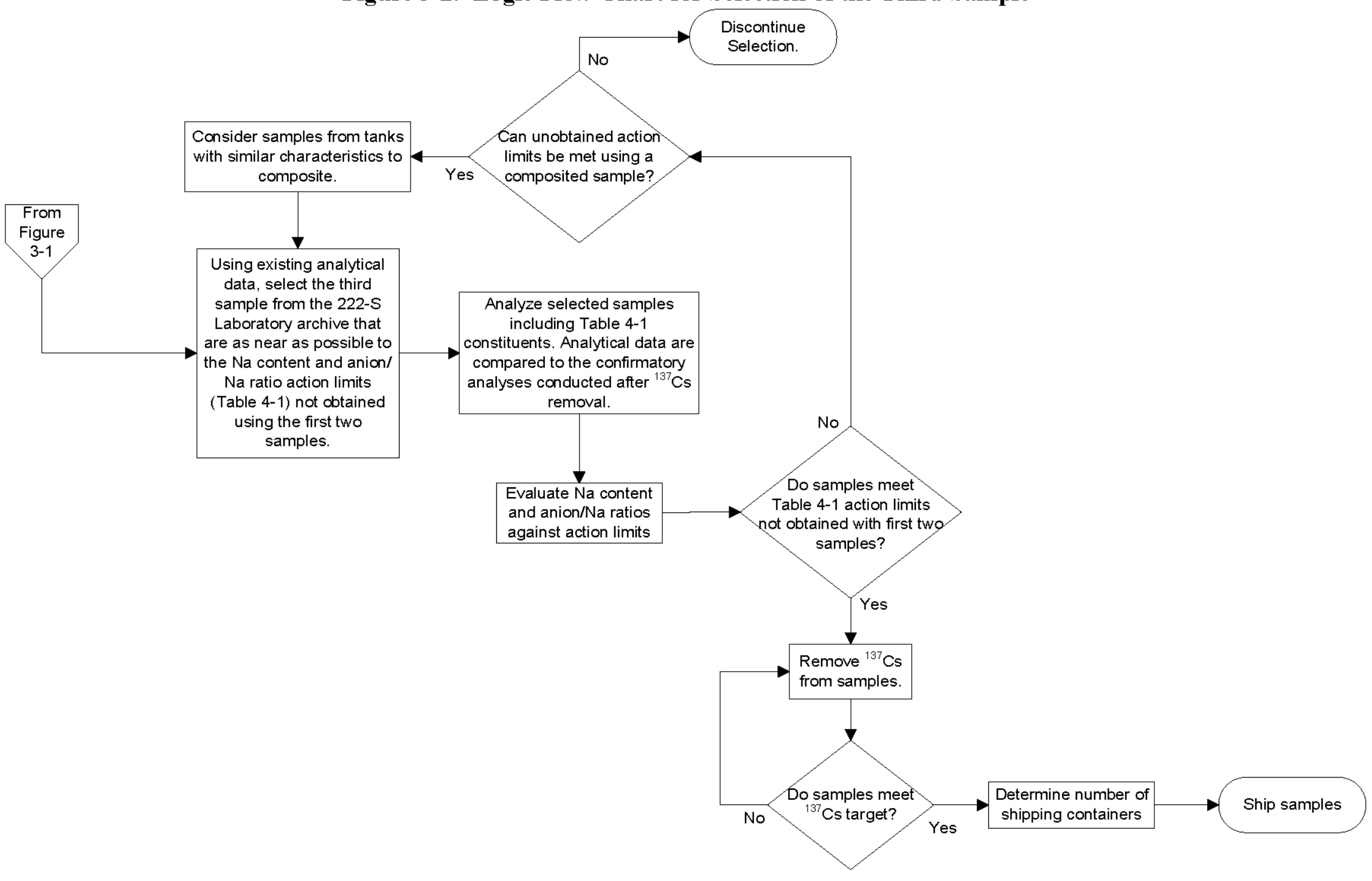




\subsection{DATA INPUTS}

Three separate samples, with different properties, will be shipped for BSR testing. Each one of the three samples may be made up of several 222-S Laboratory archived samples from the same tank or composited from different tanks. The shipped samples will be liquid; however, the samples may be prepared from dissolved archived solid samples. The general BSR testing requirements for each of the three samples are shown below. Table 4-1 shows the required analytes, the reasons for the analysis, and any action limits.

1. Contains high $\mathrm{SO}_{4}{ }^{2-}, \mathrm{Cl}^{-}, \mathrm{F}^{-}$, and $\mathrm{PO}_{4}{ }^{3-}$ relative to $\mathrm{Na}$,

2. Contains low $\mathrm{SO}_{4}{ }^{2-}, \mathrm{Cl}^{-}, \mathrm{F}^{-}$, and $\mathrm{PO}_{4}{ }^{3-}$ relative to $\mathrm{Na}$, and

3. Contains $\mathrm{SO}_{4}{ }^{2-}, \mathrm{Cl}^{-}, \mathrm{F}^{-}$, and $\mathrm{PO}_{4}{ }^{3-}$ relative to $\mathrm{Na}$ between the high and low samples.

4. Sodium quantity.

As can be seen in Figures 3-1 and 3-2, the samples will be selected from the 222-S Laboratory using existing analytical data. The selection process will be based on the information in RPP-48824, Sample Selection Process for Bench-Scale Steam Reforming Treatability Studies Using Hanford Waste Samples. The samples will be selected to match, as near as possible the action limits shown in Table 4-1.

Initially two of the three required samples are selected and analyzed. The only information needed to ship the first two samples is the radionuclide data required to ship the samples (49 CFR 173, "Shippers-General Requirements for Shipments and Packaging"), sodium content, and the ${ }^{137} \mathrm{Cs}$ (see Table 4-1). Therefore, the first two samples may be shipped before the anion/ $\mathrm{Na}$ ratios are determined. Shipping the samples prior to evaluating how well the samples meet the anion/ $\mathrm{Na}$ ratio action limits (see Table 4-1) allows the BSR testing to begin sooner by reducing the time required to ship the samples. After evaluating the anion/ $\mathrm{Na}$ ratio data from the first two samples, the third sample will be selected (see Figure 3-2) based on how well the first two samples meet the anion/ $\mathrm{Na}$ ratio action limits.

Because samples may not be available that exactly meet the anion/Na ratio action limits, a prioritization of the anions was determined. The order of importance for meeting the action limits for the anion/ $\mathrm{Na}$ ratios is $\mathrm{SO}_{4}{ }^{2-}, \mathrm{Cl}^{-}, \mathrm{F}^{-}$, and $\mathrm{PO}_{4}{ }^{3-}$ respectively. Project personnel will make the determination on the adequacy of the samples with respect to the anion/Na ratios and sodium content. Therefore, project personnel may choose to send a sample even if the action limits for the sodium content and anion/Na ratios shown in table 4-1 are not exactly met.

Figures 3-1 and 3-2 show analytical data will be collected before and after ${ }^{137} \mathrm{Cs}$ removal. The pre ${ }^{137} \mathrm{Cs}$ removal analyses will be compared to the post ${ }^{137} \mathrm{Cs}$ removal analytical data to determine the effectiveness of the ${ }^{137} \mathrm{Cs}$ removal and the effect of the ${ }^{137} \mathrm{Cs}$ removal on the samples. The analyses conducted after the ${ }^{137} \mathrm{Cs}$ removal will be used to determine sample requirements for shipping of the first two samples (see Figure 3-1).

For the third sample (see Figure 3-2) the pre ${ }^{137} \mathrm{Cs}$ removal analysis will be used to determine if the sample meets the requirements for BSR testing. Project personnel will determine if the analyses meet the requirements for BSR testing with respect to anion/ $\mathrm{Na}$ ratios and $\mathrm{Na}$ content. 
RPP-47073 Rev. 2

Table 4-1. Required Information and Action Limits

\begin{tabular}{|c|c|c|c|}
\hline Data Inputs & Action Limits & $\begin{array}{c}\text { Shipping } \\
\text { Requirement }\end{array}$ & Comments \\
\hline $\mathrm{SO}_{4}{ }^{2-}$ & $\begin{array}{c}\text { High Sample } \geq \\
0.032 \\
\text { Low Sample } \leq \\
0.008\end{array}$ & No & $\begin{array}{l}\text { The action limits are ratios of } \\
\mathrm{SO}_{4}{ }^{2-} \underline{\mathrm{M}} / \mathrm{Na} \underline{\mathrm{M}} \text {. }\end{array}$ \\
\hline $\mathrm{Cl}^{-}$ & $\begin{array}{c}\text { High Sample } \geq \\
0.016 \\
\text { Low Sample } \leq \\
0.007\end{array}$ & No & $\begin{array}{l}\text { The action limits are ratios of } \mathrm{Cl}^{-} \\
\qquad \underline{\mathrm{M}} \mathrm{Na} \underline{\mathrm{M}} .\end{array}$ \\
\hline $\mathrm{F}^{-}$ & $\begin{array}{c}\text { High Sample } \geq \\
0.06 \\
\text { Low Sample } \leq \\
0.0013\end{array}$ & No & $\begin{array}{l}\text { The action limits are ratios of } \mathrm{F}^{-} \\
\qquad \underline{\mathrm{M}} \mathrm{Na} \underline{\mathrm{M}} .\end{array}$ \\
\hline $\mathrm{PO}_{4}^{3-}$ & $\begin{array}{c}\text { High Sample } \geq \\
0.04 \\
\text { Low Sample } \leq \\
0.005\end{array}$ & No & $\begin{array}{l}\text { The action limits are ratios of } \\
\qquad \mathrm{PO}_{4}{ }^{3-} \underline{\mathrm{M}} / \mathrm{Na} \underline{\mathrm{M}} \text {. }\end{array}$ \\
\hline $\mathrm{Na}$ & 4 to $7 \mathrm{Mol} / \mathrm{L}$ & No & \\
\hline${ }^{137} \mathrm{Cs}$ & $<0.05 \mathrm{mrem}$ & Yes & This is an ALARA target. \\
\hline $\begin{array}{l}{ }^{241} \mathrm{Am}^{243}{ }^{24 m}{ }^{237} \mathrm{~Np}, \\
{ }^{90} \mathrm{Sr}{ }^{229} \mathrm{Th},{ }^{230} \mathrm{Th},{ }^{232} \mathrm{Th}, \\
{ }^{231} \mathrm{~Pa},{ }^{233} \mathrm{U},{ }^{234} \mathrm{U},{ }^{235} \mathrm{U}, \\
{ }^{236} \mathrm{U},{ }^{238} \mathrm{U},{ }^{239} \mathrm{Pu},{ }^{240} \mathrm{Pu} \\
{ }^{242} \mathrm{Pu},{ }^{244} \mathrm{Pu}\end{array}$ & See 49 CFR 173 & Yes & $\begin{array}{l}\text { Required information for } \\
\text { shipping. }\end{array}$ \\
\hline${ }^{99} \mathrm{Tc}$ & None & Yes & $\begin{array}{l}\text { Knowledge of amount in the } \\
\text { samples is needed for BSR } \\
\text { testing. The sample will be } \\
\text { spiked with }{ }^{99} \mathrm{Tc} \text { so it will contain } \\
\text { a specified amount for testing. } \\
\text { Needed for shipping } \\
\text { requirements. }\end{array}$ \\
\hline Sample mass & $<1000 \mathrm{~g}$ & No & Limit for treatability studies. ${ }^{(a)}$ \\
\hline \multicolumn{4}{|r|}{ gton Administrative Code } \\
\hline
\end{tabular}




\subsection{QUALITY CONTROL}

Laboratories and/or subcontracted laboratories performing analyses in support of this DQO document shall have approved and implemented quality assurance (QA) plans. These QA plans shall meet DOE/RL-96-68, Hanford Analytical Services Quality Assurance Requirements Documents (HASQARD) minimum requirements as the baseline for laboratory quality systems. ATL-MP-1011, ATL Quality Assurance Project Plan for 222-S Laboratory specifies the analyses conducted at the 222-S Laboratory. Analyses performed by WRPS shall be performed by ATS-MP-1032, 222-S Laboratory Quality Assurance Plan.

If subcontracting any portion of this DQO to a commercial laboratory off the Hanford Site, the Subcontractor's implementing quality assurance program shall comply with the Department of Energy Consolidated Audit Program (DOECAP) Quality Systems for Analytical Services (QSAS).

Each sample in the analytical batch will require duplicate analysis; therefore, each client sample will have a primary and duplicate value for each analyte. Other laboratory quality control will be conducted according to the criteria outlined in Table 4-2.

The preferred methods of analysis are SW-846, Test Methods for Evaluating Solid Waste, Physical/Chemical Methods, or other approved standardized methods. The most recent revisions are preferred. Conditions (e.g., quality problems) that do not conform to requirements specified in this DQO or references herein shall be controlled to prevent inadvertent use. These quality problems shall be identified, documented, controlled, and reported to prevent reoccurrence as required by ATL-312, ATL Analytical Project Process Flow procedure (Section 4.26) and ATS 310, 222-S Analytical Project Process Flow procedure (Section 1.25) parts 4.17, 4.18 and 4.19. Off-site laboratories shall initiate their corrective action process as applicable to (DOECAP) QSAS.

The radionuclide analyses will require a turnaround time of four working days. This short turnaround time governs the analytical methods that can be used for radionuclide analyses. The analyses, other than radionuclides, will require a turnaround time of ten working days. After a QA review, the analytical data will be reported by a data summary report. 
Table 4-2. Quality Control Parameters.

\begin{tabular}{|c|c|c|c|c|c|}
\hline \multirow[b]{2}{*}{ Analytes } & \multicolumn{5}{|c|}{ Quality Control Acceptance Criteria } \\
\hline & \begin{tabular}{|c|}
$\begin{array}{c}\text { Proposed Analytical } \\
\text { Methods }\end{array}$ \\
\end{tabular} & $\begin{array}{c}\text { LCS } \\
\text { \% Recovery }{ }^{(a)}\end{array}$ & $\begin{array}{c}\text { Spike } \\
\text { \% Recovery }^{(\mathbf{b})}\end{array}$ & $\begin{array}{c}\text { Duplicate RPD } \\
\text { Liquids } \\
\end{array}$ & \begin{tabular}{|c|}
$\begin{array}{c}\text { Duplicate RPD } \\
\text { Solids }\end{array}$ \\
\end{tabular} \\
\hline $\begin{array}{c}\mathrm{Ag}, \mathrm{As}, \mathrm{Ba}, \mathrm{Be}, \mathrm{Cd}, \mathrm{Cr}, \\
\mathrm{Hg}, \mathrm{Pb}, \mathrm{Na}, \mathrm{Ni}, \mathrm{Sb}, \mathrm{Se}, \mathrm{Tl} \\
\text { V, } \mathrm{Zn}\end{array}$ & ICP/AES & $80-120$ & $75-125$ & $\leq 20 \%$ & $\leq 30 \%$ \\
\hline $\mathrm{Hg}$ & CVAA & $80-120$ & $75-125$ & $\leq 20 \%$ & $\leq 30 \%$ \\
\hline $\mathrm{Cl}^{-}, \mathrm{F}^{-}, \mathrm{PO}_{4}^{3-}, \mathrm{SO}_{4}^{2-}$ & IC & $80-120$ & $75-125$ & $\leq 20 \%$ & $\leq 30 \%$ \\
\hline${ }^{90} \mathrm{Sr}$ & Beta Counting & $80-120$ & $\mathrm{~N} / \mathrm{A}^{(\mathrm{d})}$ & $\leq 20 \%$ & $\leq 30 \%$ \\
\hline $\begin{array}{c}{ }^{241} \mathrm{Am},{ }^{243} \mathrm{Am},{ }^{238} \mathrm{Pu},{ }^{239} \mathrm{Pu}, \\
{ }^{240} \mathrm{Pu},{ }^{242} \mathrm{Pu},{ }^{244} \mathrm{Pu},{ }^{237} \mathrm{~Np}, \\
{ }^{229} \mathrm{Th},{ }^{230} \mathrm{Th},{ }^{232} \mathrm{Th},{ }^{231} \mathrm{~Pa}, \\
{ }^{233} \mathrm{U},{ }^{234} \mathrm{U},{ }^{235} \mathrm{U},{ }^{236} \mathrm{U},{ }^{238} \mathrm{U},\end{array}$ & $\mathrm{ICP} / \mathrm{MS}$ & $80-120^{(\mathrm{e})}$ & $75-125^{(\mathrm{e})}$ & $\leq 20 \%$ & $\leq 30 \%$ \\
\hline${ }^{99} \mathrm{Tc}$ & Liquid Scintillation & $80-120$ & $75-125$ & $\leq 20 \%$ & $\leq 30 \%$ \\
\hline${ }^{137} \mathrm{Cs}$ & GEA & $80-120$ & $\mathrm{~N} / \mathrm{A}^{(\mathrm{f})}$ & $\leq 20 \%$ & $\leq 30 \%$ \\
\hline TOC & $\begin{array}{c}\text { Silver catalyzed } \\
\text { persulfate oxidation }\end{array}$ & $80-120$ & $75-125$ & $\leq 20 \%$ & $\leq 30 \%$ \\
\hline
\end{tabular}

Notes:

N/A $=$ Not Applicable

$\mathrm{TOC}=$ total organic carbon

(a) LCS = Laboratory Control Sample. This sample is carried through the entire method. The accuracy of a method is usually expressed as the percent recovery of the LCS. The LCS is a matrix with known concentration of analytes processed with each preparation and analyses batch. It is expressed as percent recovery; i.e., the amount measured, divided by the known concentration, times 100.

(b) For some methods, the sample accuracy is expressed as the percent recovery of a matrix spike sample. It is expressed as percent recovery; i.e., the amount measured, less the amount in the sample, divided by the spike added, times 100 . One matrix spike is performed per analytical batch. Samples are batched with similar matrices.

(c) $\mathrm{RPD}=$ Relative Percent Difference between the analytical samples. Analytical precision is estimated by analyzing duplicates taken separately through preparation and analysis. RPD for PCBs may be calculated using matrix spike and matrix spike duplicate results. Acceptable analytical precision is usually $\leq 20 \%$ RPD for liquids and $\leq 30 \%$ for solids if the sample result is at least 10 times the instrument detection limit. $\mathrm{RPD}=(($ absolute difference between primary and duplicate $) /$ mean $) \times 100$

(d) Matrix spike analyses are not required for this method because a carrier or tracer is used to correct for constituent loss during sample preparation and analysis. The result generated using the carrier or tracer accounts for any inaccuracy of the method on the matrix. The reported results reflect this correction.

(e) The measurement is a direct reading of the energy and the analysis is not affected by the sample matrix; therefore, a matrix spike is not required.

(f) Standards are only available for the following analytes ${ }^{241} \mathrm{Am},{ }^{239} \mathrm{Pu},{ }^{237} \mathrm{~Np},{ }^{232} \mathrm{Th},{ }^{235} \mathrm{U}$, and ${ }^{238} \mathrm{U}$.

\subsection{STUDY BOUNDARIES}

This step in the DQO process defines the spatial and temporal boundaries for the required sampling and analyses needed to make the necessary decisions. The spatial boundaries define the physical area to which the decisions will apply and where the samples should be taken. The temporal boundaries describe the timeframe the data will represent, and when the samples should be taken. In addition, this portion of the DQO addresses any sampling constraints. 


\subsection{SPATIAL AND TEMPORAL BOUNDARIES}

Presently, the spatial boundaries for this DQO include only the archived samples (liquid and solid) of Hanford tank waste located at the 222-S Laboratory.

This DQO will be in effect until the BSR testing is concluded and no additional sample selection is required.

\subsection{SAMPLING CONSTRAINTS}

The biggest constraint to obtaining the required samples is the availability of appropriate waste (quantity and type) in the 222-S Laboratory. However, as stated in Section 4.0, each one of the samples to be shipped may be made up of several 222-S Laboratory archived samples.

\subsection{DECISION RULES}

The DQO process includes development of decision rules, which define the actions to be taken as a result of exceeding an action limit. Decision rules are expressed as "if...then" statements that incorporate, as available, the parameter of interest, the scale of decision making, the action limit, and the actions that would result from resolution of the decision rule.

Commonly, an action limit is a concentration at which point a predetermined action is taken depending on whether the results of the analyses are above or below the specified action limit. To account for uncertainty in the data, analytical results are compared to the action limit at a statistical confidence interval previously agreed upon. In the case of this DQO, the means of the analytical data (primary and duplicate) are considered adequate to make the comparison to the action limits shown in Table 4-1. In addition, with the exception of shipping requirements, the action limits are targets and the final decisions to ship the samples will be made by project personnel and no additional statistical calculations are required.

As can be seen in Figures 3-1 and 3-2, initially only two samples are selected from the 222-S Laboratory archived samples. After the analytical results of the two initial samples are known and evaluated, the third sample will be selected. The samples are selected using existing data and guided by RPP-48824.

As stated in Section 4.0, the decision to ship the first two samples (see Figure 3-1) is based on the shipping requirements, sodium content, and the ${ }^{137} \mathrm{Cs}$ concentrations. The decision rule addresses the requirement to remove radionuclides from the samples prior to shipment and the sodium content. Additional informational data are needed to address shipping requirements.

For the first two samples, decisions are made using the post ${ }^{137} \mathrm{Cs}$ removal analyses. The decision rule for the initial two samples (see Figure 3-1) can be written as: 
If the average of the post ${ }^{137} \mathrm{Cs}$ removal analyses for the first two samples shows the samples meet the shipping requirements, the ${ }^{137} \mathrm{Cs}$ concentration meets the ALARA target, and the sodium content is within the sodium range (see Table 4-1), then ship the samples; otherwise, remove additional ${ }^{137} \mathrm{Cs}$ (if required), or obtain additional sample material and repeat the process.

For the third sample, decisions are made using the pre and post ${ }^{137} \mathrm{Cs}$ removal analyses. The two decision rules for the third sample (see Figure 3-2) can be written as follows.

1. If the average of the pre ${ }^{137} \mathrm{Cs}$ removal analyses for the third sample shows the sample meets the anion/ $\mathrm{Na}$ ratio not met in the first two samples and sodium content, then remove the ${ }^{137} \mathrm{Cs}$; otherwise, select alternative archived samples or discontinue sample selection.

2. If the average of the post ${ }^{137} \mathrm{Cs}$ removal analyses for the third samples shows the ${ }^{137} \mathrm{Cs}$ concentration meets the ALARA targets (see Table 4-1), then ship the sample; otherwise, remove additional ${ }^{137} \mathrm{Cs}$ before shipping the sample.

\subsection{ERROR TOLERANCE}

The uncertainty in the DQO process provides an evaluation of the probability of decision error based on an estimation of the mean, variance, and number of samples. The uncertainty evaluation is used to assess the accuracy and precision specified for sample collection and analysis, the level of decision error, and the number of samples required to meet a given decision error rate.

As stated in Section 6.0, the project team determined the means of the analytical data (primary and duplicate) are adequate to make the comparison to the action limits shown in Table 4-1. Therefore, if the mean of the analytical data meets the appropriate action limits or if a subjective determination is made that the sample is suitable for testing then the samples can be used and no additional uncertainty calculations are required.

\subsection{SAMPLING DESIGN}

Sampling for this DQO consists of selecting archived tank waste samples from the 222-S Laboratory and selecting subsamples for confirmatory analyses. Three samples will be selected and shipped for BSR testing. The sample selection will be based on previous analytical data in sufficient quantity for BSR testing. Separate archived samples from the same tank or separate tanks may be combined to provide a sufficient quantity for the test sample.

Because of the nature of "sampling" for this DQO, sample optimization is not applicable. Sample collection will be based on the criteria shown in Table 4-1. 
RPP-47073 Rev. 2

\subsection{REFERENCES}

49 CFR 173, "Shippers-General Requirements for Shipments and Packaging," Code of Federal Regulations, as amended

ATL-MP-1011, ATL Quality Assurance Project Plan for 222-S Laboratory, as revised, Advanced Technologies and Laboratories International, Inc., Richland, Washington.

ATL-312, ATL Analytical Project Process Flow, Section 4.26, as revised, Advanced Technologies and Laboratories International, Inc., Richland, Washington.

ATS-MP-1032, 222-S Laboratory Quality Assurance Plan, as revised, Washington River Protection Solutions LLC, Richland, Washington.

ATS 310, 222-S Analytical Project Process Flow, Section 1.25, as revised, Washington River Protection Solutions LLC, Richland, Washington.

DOECAP, Department of Energy Consolidated Audit Program Quality Systems For Analytical Services, as revised, U.S. Department of Energy, Oak Ridge Office, Oak Ridge, Tennessee.

DOE/RL-96-68, 2007, Hanford Analytical Services Quality Assurance Requirements Documents, Rev. 3, U.S. Department of Energy, Richland Operations Office, Richland, Washington.

EPA QA/G-4, 2006, Guidance on Systematic Planning Using the Data Quality Objectives Process, U.S. Environmental Protection Agency Quality Assurance Management Staff, Washington, D.C.

RPP-48824, 2010, Sample Selection Process for Bench-Scale Steam Reforming Treatability Studies Using Hanford Tank Waste, Rev. 0, Washington River Protection Solutions LLC, Richland, Washington.

SW-846, 1986, Test Methods for Evaluating Solid Waste, Physical/Chemical Methods, Third Edition, as amended, U.S. Environmental Protection Agency, Washington, D.C.

TFC-ENG-CHEM-C-16, Data Quality Objectives for Sampling and Analyses, as revised, Washington River Protection Solutions LLC, Richland, Washington.

WAC 173-303-071, "Excluded Categories of Waste," Washington Administrative Code, as amended. 


\section{DISTRIBUTION SHEET}

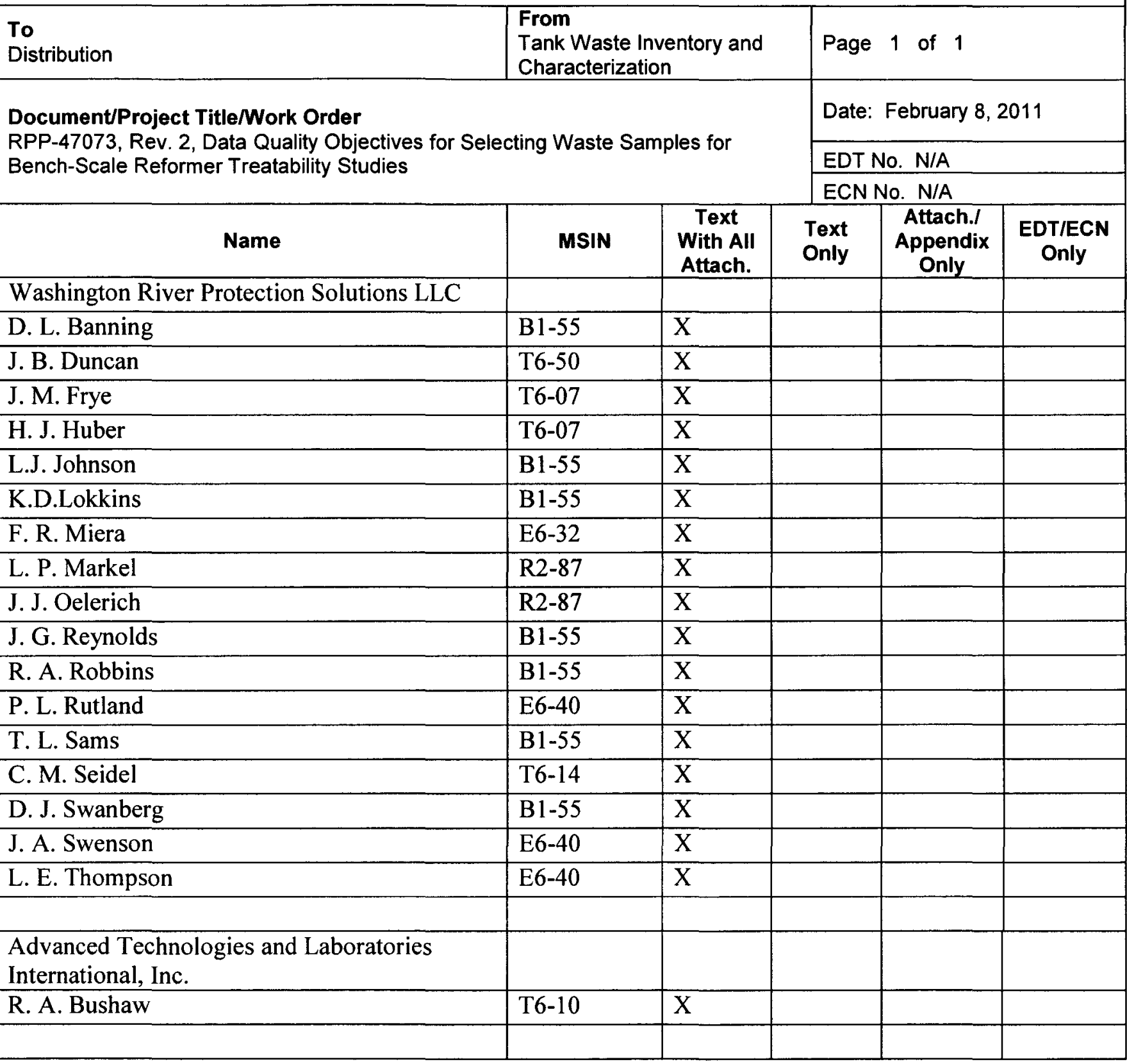

